\title{
Bactericidal Effects of
} Exiguobacterium sp GM010 Pigment Against Food-Borne Pathogens

\author{
Krishna-Prashanth Ramesh Mekala ${ }^{1,2}$, Saritha G. Pandit ${ }^{1,2}$ and Mohan A. Dhale 1,2* \\ ${ }^{1}$ Department of Microbiology and Fermentation Technology, Central Food Technological Research Institute, Mysore, India, \\ ${ }^{2}$ Academy of Scientific and Innovative Research (AcSIR), Ghaziabad, India
}

\section{OPEN ACCESS}

Edited by:

Lourdes Morales-Oyervides, Universidad Autónoma de

Coahuila, Mexico

Reviewed by:

Palanivel Velmurugan, Alagappa University, India Guadalupe Virginia Nevárez-Moorillón,

Autonomous University of Chihuahua, Mexico

*Correspondence:

Mohan A. Dhale mohana@cftri.res.in;

dhalemohan@yahoo.com

Specialty section:

This article was submitted to Sustainable Food Processing,

a section of the journal

Frontiers in Sustainable Food Systems

Received: 18 May 2020

Accepted: 05 August 2020 Published: 22 September 2020

Citation:

Mekala K-PR, Pandit SG and Dhale MA (2020) Bactericidal Effects of Exiguobacterium sp GM010 Pigment Against Food-Borne Pathogens. Front. Sustain. Food Syst. 4:142. doi: 10.3389/fsufs.2020.00142
Bacterium producing yellowish-orange pigment was identified (morphological, biochemical, and 16S rRNA) as Exiguobacterium sp GM010. The UV-visible spectrum of Exiguobacterium sp GM010 extract showing $\lambda \max$ at $465 \mathrm{~nm}$ revealed orange pigment characteristic. Pigment showed broad spectrum antibacterial action against gram positive and gram negative food-borne pathogens. The SYTO9 and propidium iodide (PI) staining revealed the cell membrane damage of food-borne pathogens under confocal laser scanning microscope (CLSM) indicating the bactericidal effect. This was evidenced by the fourier transform infrared (FTIR) spectrum, showing characteristic functional groups that mainly included hydroxyl, carbonyl, and carboxylic groups causing a system of delocalized electrons leading to destabilization of membrane and decrease in membrane potential that resulted in bactericidal effect. The pigment of Exiguobacterium sp GM010 were non-toxic against Artemia franciscana and can be a promising source to control the food-borne pathogens in food industries.

Keywords: Exiguobacterium sp GM010, pigment, marine bacteria, antimicrobial, food-borne pathogens

\section{INTRODUCTION}

Food-borne diseases have become one of the most widespread public health problems. About two-thirds of all the outbreaks were due to consumption of microorganisms contaminated food and water. World Health Organization (WHO) estimates, unsafe food causes 600 million cases of food-borne diseases and 4,20,000 deaths annually, including children (Bajpai et al., 2013; Fukuda, 2015; World Health Organization, 2020). Hence, food safety is a major concern not only for developing countries but also for the developed countries. A study was conducted to characterize the prevalence and diversity of food-borne pathogens, recommended to minimize the risk of contamination in fields (Strawn et al., 2013). Recent reports have identified the prevalence of bacterial pathogens in quality export seafood (Bandekar, 2015) causes massive economic losses to the food industry.

To reduce the health risks and economic losses, the foods are treated with antimicrobial agents as preservative. There has been a major focus on the development of safe and efficient natural broad spectrum antimicrobials that can replace synthetic alternatives (Kim et al., 2013; Al-zoreky and Al-Taher, 2015). The marine microorganisms are excellent source of bioactive compounds, where antimicrobial compounds stand in the majority (Burgess et al., 1999; Nithyanand et al., 2011; Wiese and Imhoff, 2019). Many marine microorganisms have been isolated from different marine habitats to discover new bioactive compounds (Blunt et al., 2012, 2014). These bioactive compounds have a considerable importance (Newman and Cragg, 2007) for drug discovery industry due to their 
TABLE 1 | Antimicrobial activity of pigment of Exiguobacterium sp GM010 against food-borne pathogens.

\begin{tabular}{|c|c|c|c|c|c|c|c|c|}
\hline \multirow[t]{3}{*}{ Strain/antibiotics } & \multicolumn{8}{|c|}{ Inhibition zone $(\mathrm{mm})^{*}$} \\
\hline & \multicolumn{5}{|c|}{ Gram-positive } & \multicolumn{3}{|c|}{ Gram-negative } \\
\hline & $\begin{array}{l}\text { B. cereus } \\
\text { ATCC } \\
11778\end{array}$ & $\begin{array}{l}\text { B. subtilis } \\
\text { ATCC } \\
06633\end{array}$ & $\begin{array}{l}\text { S. aureus } \\
\text { FRI722 }\end{array}$ & $\begin{array}{l}\text { M. luteus } \\
\text { ATCC } \\
9341\end{array}$ & $\begin{array}{l}\text { L. monocytogenes } \\
\text { Scott A }\end{array}$ & $\begin{array}{l}\text { E. coli } \\
\text { EFR02 }\end{array}$ & $\begin{array}{l}\text { P. aeruginosa } \\
\text { ATCC } \\
15442\end{array}$ & $\begin{array}{c}\text { Klebsiella } \\
\text { sp }\end{array}$ \\
\hline Exiguobacterium sp GM010 & $7.16 \pm 0.28$ & $7.66 \pm 0.57$ & $8.5 \pm 0.5$ & $10.83 \pm 0.36$ & $14.33 \pm 0.57$ & $6.66 \pm 0.28$ & $8.16 \pm 0.28$ & $8.1 \pm 0.0 .28$ \\
\hline AMP & 10 & 16 & 12 & 16 & 18 & 10 & 8 & 11 \\
\hline TET & 18 & 18 & 16 & 21 & 21 & 12 & 16 & 16 \\
\hline CIP & 16 & 19 & 14 & 23 & 18 & 14 & 15 & 14 \\
\hline
\end{tabular}

*Zone of inhibition including the disc.

AMP, Ampicillin; TET, Tetracycline; CIP, Ciprofloxacin are standard broad spectrum antibiotics.

structural diversity and biological activity. More than 22,000 bioactive compounds from marine organisms have been reported (Demain and Sanchez, 2009) that includes both prokaryotes and eukaryotes. The Streptomyces sp was widely studied microbial species from Indian coastal waters as a source of antibiotics (Chandramohan, 1997; Valliappan et al., 2014). There are report on the algicidal (Li et al., 2016), antifungal (Selvakumar et al., 2009) and antibacterial (Shanthakumar et al., 2015) effect of Exiguobacterium species, however mechanism of antibacterial effect of Exiguobacterium pigment on food-borne pathogens was not reported. In this study pigment producing Exiguobacterium sp GM010 was isolated, and characterized. The antibacterial properties of pigment against the food-borne pathogens, mode of action, and non-toxic effect suggested the potential applications in food industries.

\section{MATERIALS AND METHODS}

\section{Food-Borne Pathogens}

Food-borne pathogens Escherichia coli EFR02, Staphylococcus aureus FRI722, Pseudomonas aeruginosa ATCC 15442, Bacillus subtilis subsp spizizenii ATCC 06633, B. cereus ATCC 11778, Klebsiella sp, Listeria monocytogenes Scott A, and Micrococcus luteus ATCC 9341 were obtained from Food Safety and Analytical Quality Control Laboratory, CSIR-Central Food Technological Research Institute, Mysore, Karnataka, India. Stock cultures of pathogens were maintained on nutrient agar at $4^{\circ} \mathrm{C}$ and subcultured in nutrient broth at $37^{\circ} \mathrm{C}$, before activity assay.

\section{Isolation and Identification}

Sediment samples collected from Tamil Nadu coastal regions were used for isolation of bacteria. The isolated chromosomal DNA (Marmur, 1961) was amplified using universal primers 27F (50-AGA GTT TGA TCC TGG CTC AG-30) and 1492R (50-GGT TAC CTT GTT ACG ACT T-30) (Lane, 1991). The $16 \mathrm{~S}$ rRNA gene sequence was compared using the NCBI BLAST for similarity with the reference bacterial species in GenBank database. Multiple alignments of the sequences using the Clustal $\mathrm{W}$ program and phylogenetic tree construction using treeing algorithms were performed in MEGA X software package.

\section{Antibacterial Activity and Mode of Action}

The strain GM010 was inoculated into $100 \mathrm{ml}$ of zobell marine broth $(\mathrm{ZMB})$ in $250 \mathrm{ml}$ conical flask and incubated for 3 days at $30^{\circ} \mathrm{C}, 150 \mathrm{rpm}$. After incubation, the pigment was extracted by solvent-solvent partition by adding equal volume of ethyl acetate to the culture broth. Ethyl acetate fraction was separated and concentrated. The stock of pigment was prepared by dissolving in DMSO (50 mg/ml) for antibacterial assay (Dhale et al., 2007). The overnight grown food-borne pathogen (Table 1) bacterial cultures $(200 \mu \mathrm{l})$ were spread on nutrient agar. The $6 \mathrm{~mm}$ disks impregnated with the $200 \mu \mathrm{g}$ of GM010 pigment were placed and incubated at $37^{\circ} \mathrm{C}$ for $24-48 \mathrm{~h}$. The activity was determined by measuring the inhibition zones. The disks with DMSO and standard antibiotics were used as negative and positive control, respectively.

\section{Confocal Laser Scanning Microscopy (CLSM)}

The mode of inhibition of food-borne pathogens, was determined using LIVE/DEAD BacLight ${ }^{\mathrm{TM}}$ Bacterial Viability Kit (Invitrogen, Molecular probes Inc) according to manufacture's protocols. One $\mathrm{ml}$ of food-borne pathogen cells were treated with $200 \mu \mathrm{g}$ of GM010 pigment in centrifuge tubes. After removing growth medium, the cells were washed with $0.85 \%$ saline and mixture of SYTO9 and propidium iodide (PI) was added to the treated cell. This was incubated in dark at room temperature for 20-25 min in dark. After incubation, the images were acquired in Zeiss LSM 700 CSLM to analyze samples. Images were acquired with $512 \times 512$ resolutions in at least three different fields. Zeiss ZEN software was used to acquire images. The laser was used at $488 \mathrm{~nm}$ for excitation and the emission was observed at $528 \mathrm{~nm}$ (SYTO9) and $645 \mathrm{~nm}(\mathrm{PI})$.

\section{Scanning Electron Microscopic (SEM)}

The morphological changes of food-borne pathogen cells were analyzed after treatment with GM010 pigment under SEM (Asensioa et al., 2005). Briefly, $1 \mathrm{ml}$ of bacterial culture was added to centrifuge tube containing $200 \mu \mathrm{g}$ of pigment. This was centrifuged after incubation at $37^{\circ} \mathrm{C}$ for $6 \mathrm{~h}$, the pellets were rinsed with phosphate buffer and fixed with $3 \%$ glutaraldehyde 
A

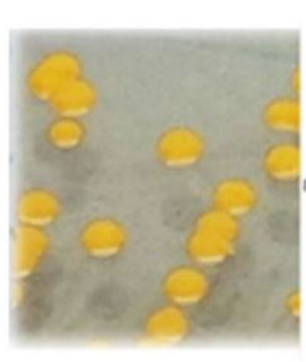

B
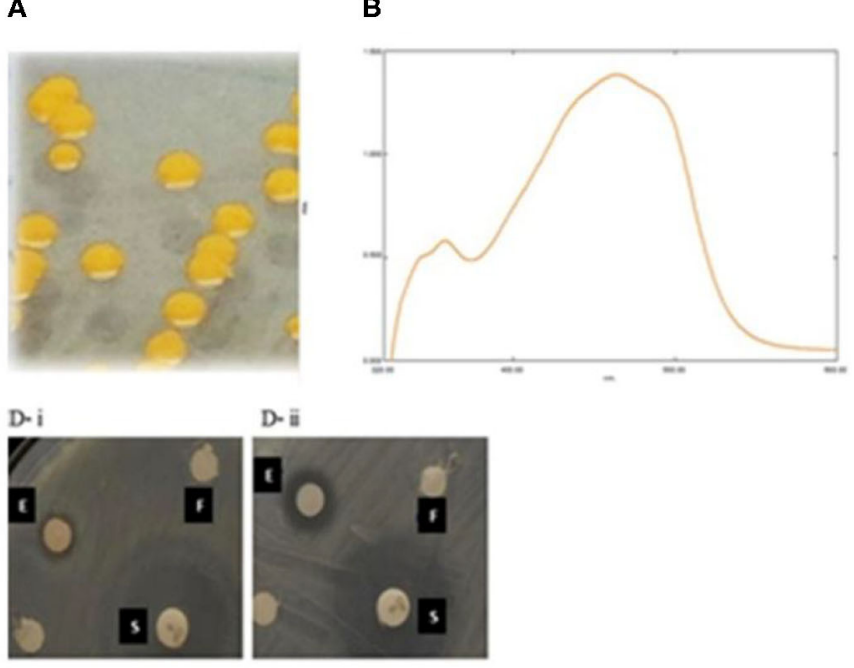

D- : iㅛ

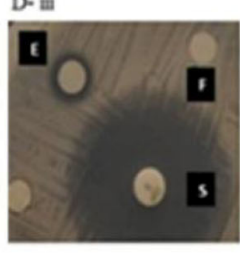
D. is

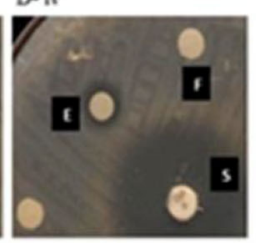

C
4 Exiguobacterium sp. strain GM010 KY014429.1 - Exiguobacterium sp. HL.95 KC705338.1 Exiguobacterium aurantiacum strain 20E GU186196.1

99 Firmicutes bacterium X3 EF634288.1

Exiguobacterium sp. strain B84 KY452355.1

13 — Exiguobacterium sp. LKA-011 JN626953.1 - Exiguobacterium sp. strain Firmi-55 MH683144.1

6B-1 Exiguobacterium sp. strain BAB-5887 KX609731.1 $\$ 1$ Exiguobacterium aurantiacum strain MTA-23-1 KJ401068.1 Exiguobacterium sp. strain GP46 MK571476.1

51 [21 Exiguobacterium homiense strain MSEH8 KJ452466.1

38 Exiguobacterium mexicanum strain EB153 MH127585.1

57.

Exiguobacterium aurantiacum strain F41 KU922382.1

Exiguobacterium himgiriensis strain AF12 MT214250.1

43

78 - Exiguobacterium acetylicum strain S15 MK100776.1

Exiguobacterium sp. Hilsa-KRC-2 KT962244.1

Exiguobacterium sp. EH7 GU339237.1

Exiguobacterium aurantiacum strain NB11 3A JN644574.1

FIGURE 1 | The pigmentation was observed on zobell marine agar by strain GM010 (A) and the extract of strain GM010 showing absorption peak at 465 nm confirmed the pigment production (B). Based on 16S rRNA gene sequence, neighbor-joining phylogenetic tree showing the relationship of strain GM010 with related species of Exiguobacterium (C). Numbers at the nodes indicate percentage bootstrap values (500 replicates). Disc diffusion assay (D) showing inhibitory action of Exiguobacterium sp GM010 (E) against food-borne pathogens B. cereus ATCC 11778 (i), S. aureus FRI722 (ii), Klebsiella sp (iii) and E. coli EFR02 (iv). The DMSO (F) and standard antibiotic (S) were used as negative control and positive control, respectively.

TABLE 2 | Minimal inhibitory concentration and minimal bactericidal concentration of pigment of Exiguobacterium GM010 against food-borne pathogens.

\begin{tabular}{|c|c|c|c|c|c|c|c|c|c|c|c|c|c|c|c|c|}
\hline \multirow{3}{*}{$\begin{array}{l}\text { Strain/ } \\
\text { Antibiotics } \\
(\mu \mathrm{g} / \mathrm{ml})\end{array}$} & \multicolumn{10}{|c|}{ Gram +ve } & \multicolumn{6}{|c|}{ Gram -ve } \\
\hline & \multicolumn{2}{|c|}{$\begin{array}{c}\text { B. cereus } \\
\text { ATCC } 11778\end{array}$} & \multicolumn{2}{|c|}{$\begin{array}{c}\text { B. subtilis } \\
\text { ATCC } 06633\end{array}$} & \multicolumn{2}{|c|}{$\begin{array}{l}\text { S. aureus } \\
\text { FRI722 }\end{array}$} & \multicolumn{2}{|c|}{$\begin{array}{l}\text { M. luteus } \\
\text { ATCC } 9341\end{array}$} & \multicolumn{2}{|c|}{$\begin{array}{l}\text { L. monocytogenes } \\
\text { Scott A }\end{array}$} & \multicolumn{2}{|c|}{$\begin{array}{l}\text { E. coli } \\
\text { EFR02 }\end{array}$} & \multicolumn{2}{|c|}{$\begin{array}{c}P . \\
\text { aeruginosa } \\
\text { ATCC } 15442\end{array}$} & \multicolumn{2}{|c|}{ Klebsiella sp } \\
\hline & $M I C$ & MBC & $M I C$ & MBC & $M I C$ & MBC & $M I C$ & $M B C$ & $M I C$ & $M B C$ & $M I C$ & MBC & MIC & $M B C$ & MIC & МBC \\
\hline $\begin{array}{l}\text { Exiguobacterium } \\
\text { sp GM010 }\end{array}$ & 125 & 250 & 125 & 250 & 125 & 250 & 62.5 & 125 & 62.5 & 125 & 250 & 500 & 125 & 250 & 125 & 250 \\
\hline AMP & 10 & 20 & 10 & 20 & 10 & 20 & 5 & 10 & 5 & 10 & 10 & 20 & 5 & 10 & 10 & 20 \\
\hline TET & 5 & 10 & 5 & 10 & 5 & 10 & 10 & 20 & 10 & 20 & 5 & 10 & 10 & 20 & 5 & 10 \\
\hline
\end{tabular}

AMP, Ampicillin; TET, Tetracycline are standard broad-spectrum antibiotics.

for overnight in refrigerator $\left(4^{\circ} \mathrm{C}\right)$. After dehydration with series of ethanol, sample were examined under SEM (LEO 435VP, Japan). Tetracycline was used as positive control.

\section{UV-Visible and FT-IR Spectroscopy}

The UV-visible spectrum was recorded (UV-Visible 2450, Shimadzu Spectrophotometer, Japan) in the range of 400$700 \mathrm{~nm}$ to determine the pigment characteristic. The FT-IR spectrum was recorded using a fourier transform infrared (FTIR) spectrophotometer (Bruker IFS 25 model, Bruker,
Germany) in the $4,000-400 \mathrm{~cm}^{-1}$ range in transmission mode. The characteristic functional groups of GM010 pigment were identified.

\section{Determination of MIC and MBC}

The minimum inhibitory concentration (MIC) and minimum bactericidal concentration $(\mathrm{MBC})$ of pigment was determined by broth microdilution method (Pandit et al., 2018). All tests were performed in nutrient broth. Overnight bacterial culture broth of each strain were prepared and the final concentration in each 
well was adjusted to $2 \times 10^{4} \mathrm{cfu} / \mathrm{ml}$. A serial doubling dilution of the pigment was prepared in a 96-well microtiter plate over the range $15.625-2000 \mu \mathrm{g} / \mathrm{ml}$. The plates were incubated at $37^{\circ} \mathrm{C}$ for $24 \mathrm{~h}$. To determine $\mathrm{MBC}$, the pigment treated broth from each well was inoculated on nutrient agar and incubated for $24 \mathrm{~h}$ at $37^{\circ} \mathrm{C}$. Ampicillin and Tetracycline were used as positive control over the range of $1.25-160 \mu \mathrm{g} / \mathrm{ml}$. The controls were maintained without pigment to demonstrate growth of bacterial pathogen.

\section{Toxicity Assay}

Toxicity assay was performed using Artemia franciscana nauplii (Pandit et al., 2019). About $100 \mu \mathrm{l}$ of growth medium containing $\sim 26$ nauplii were used for bioassay in microtiter plates. The GM010 pigment (100 and $1,000 \mu \mathrm{g} \mathrm{ml}^{-1}$ ) was added to microtiter plates and incubatted at $27 \pm 2{ }^{\circ} \mathrm{C}$ for $36 \mathrm{~h}$. Artificial sea water was used as negative control and potassium cyanide was used as positive control. The viability of cysts was monitored at different time intervals of $12,24,36 \mathrm{~h}$ independently (Babu et al., 2015). Under 10x magnification, percentage mortality was calculated using the formula.

$$
\text { Mortality rate }(\%)=\frac{\text { Death nauplii } \times 100}{\text { Total nauplii }}
$$

\section{Statistical Analysis}

Data were expressed as the mean \pm standard deviation of triplicate measurements. Results were processed by 1-way analysis of variance (ANOVA). A Duncan multiple range test was used to determine significant differences. Differences at $P<0.05$ were considered as significant.

\section{RESULTS}

\section{Isolation of Active Strain}

The heterotrophic marine bacteria were isolated on five different culture media from the samples collected from different ecological niche. Based on morphological characteristics 43 strains were selected to isolate antagonistic strains. Since the selection of antagonistic strains was usually affected by the species and number of indicator microorganisms (Shnit-Orland and Kushmaro, 2009), all 43 strains were screened against both Gram positive and Gram negative food-borne pathogens (Data not shown). Among these, pigment of strain GM010 inhibited both Gram-positive and Gram-negative bacteria compared to broad spectrum antibiotics. The antimicrobial activities showing the zone of inhibitions were summarized in Table 1.

\section{Identification and Characterization}

The isolate GM010 produced yellow to orange pigmentation on ZMA (Figure 1A). The physiological and biochemical characteristics of the strain GM010 were presented in Table S1. UV-vis spectrum of GM010 pigment showed absorption peak at $460-470 \mathrm{~nm}$ indicating orange pigment characteristic (Figure 1B). The 16S rRNA sequence analysis revealed that, the bacterium belongs to the phylum Firmicutes and Bacillaceae family. The strain GM010 was closely related to Exiguobacterium sp HL95 (Figure 1C). Therefore, the strain GM010 was a species of genus Exiguobacterium for which Exiguobacterium sp GM010 was proposed. The sequences were submitted in GenBank with accession number KY014429 (https://www.ncbi.nlm.nih. gov/genbank/).

Further to consider the applications of the pigment, the antibacterial functional properties were evaluated (Figure 1D). The zone of inhibition were observed in the range of 6.6$14.3 \mathrm{~mm}$. The Exiguobacterium sp GM010 pigment has strongly inhibited L. monocytogenes Scott A $(14.33 \mathrm{~mm})$ followed by M. luteus ATCC $9341(10.83 \mathrm{~mm})$ compared to other food borne pathogens. Whereas, zone of inhibition for $E$. coli EFR02 observed was $6.66 \mathrm{~mm}$. Further, the MIC values of Exiguobacterium sp GM010 pigment against the food-borne pathogens were found to be in the range of $62.5-500 \mu \mathrm{g} / \mathrm{ml}$. The pigment was tested against both Gram positive and negative bacteria for antibacterial activity with a broth dilution microtiter system. The pigment inhibited L. monocytogenes Scott A and M. luteus ATCC 9341 at minimum concentration of $62.5 \mu \mathrm{g} / \mathrm{ml}$ and Klebsiella sp followed by $P$. aeruginosa ATCC 15442 was inhibited at minimum concentration of $250 \mu \mathrm{g} / \mathrm{ml}$. Whereas, E. coli EFR02 was inhibited at $500 \mu \mathrm{g} / \mathrm{ml}$ concentration of pigment (Table 2). Even though these results revealed that Exiguobacterium sp GM010 pigment can inhibit both grampositive and gram-negative food-borne pathogens, the MIC values were greatly varied. MIC determines antimicrobial susceptibility and sensitivity by measuring inhibition of bacterial growth. Whereas, $\mathrm{MBC}$ is the lowest concentration of test sample that results in a $99.9 \%$ reduction in the initial microbial density. MBCs values were generally within a two-fold dilution of the MIC value.

\section{Mode of Antibacterial Action}

The CLSM studies revealed mode of antibacterial action of Exiguobacterium sp GM010 pigment on food-borne pathogens. The SYTO9 and PI staining indicated loss of membrane integrity of food-borne pathogens treated with Exiguobacterium sp GM010 pigment and compared with tetracycline treatment. The appearance of red and yellow fluorescence indicated dead cells. Whereas, the live cells appeared green (control) did not receive any treatment (Figure 2). These results confirmed that, Exiguobacterium sp GM010 pigment disrupted the cell membrane of food-borne pathogens leading to bactericidal action. Further SEM observations revealed morphological deformation of food-borne pathogen cells, while untreated (control) cells were uniform in shape (Figure 3). The distorted structure as indicated by low electron density regions, ruptured cell wall, and cavity formation in the bacterial cells. Similar effects were also observed in tetracycline treatment (Figure 3).

The results of FT-IR spectrum of Exiguobacterium sp GM010 pigment revealed absorption bands characteristic for the functional groups of the components (Figure 4). Infrared spectrum showed characteristic functional groups that mainly included hydroxyl, carbonyl, and carboxylic groups. The strong broad band at $3,459 \mathrm{~cm}^{-1}$ was assigned to the presence of $\mathrm{OH}$ stretching in hydrogen bonds and $\mathrm{N}-\mathrm{H}$ vibration. Absorption peaks between 2999 and $2915 \mathrm{~cm}^{-1}$ correlated to stretching frequencies of aliphatic C-H groups. This spectrum showed an 


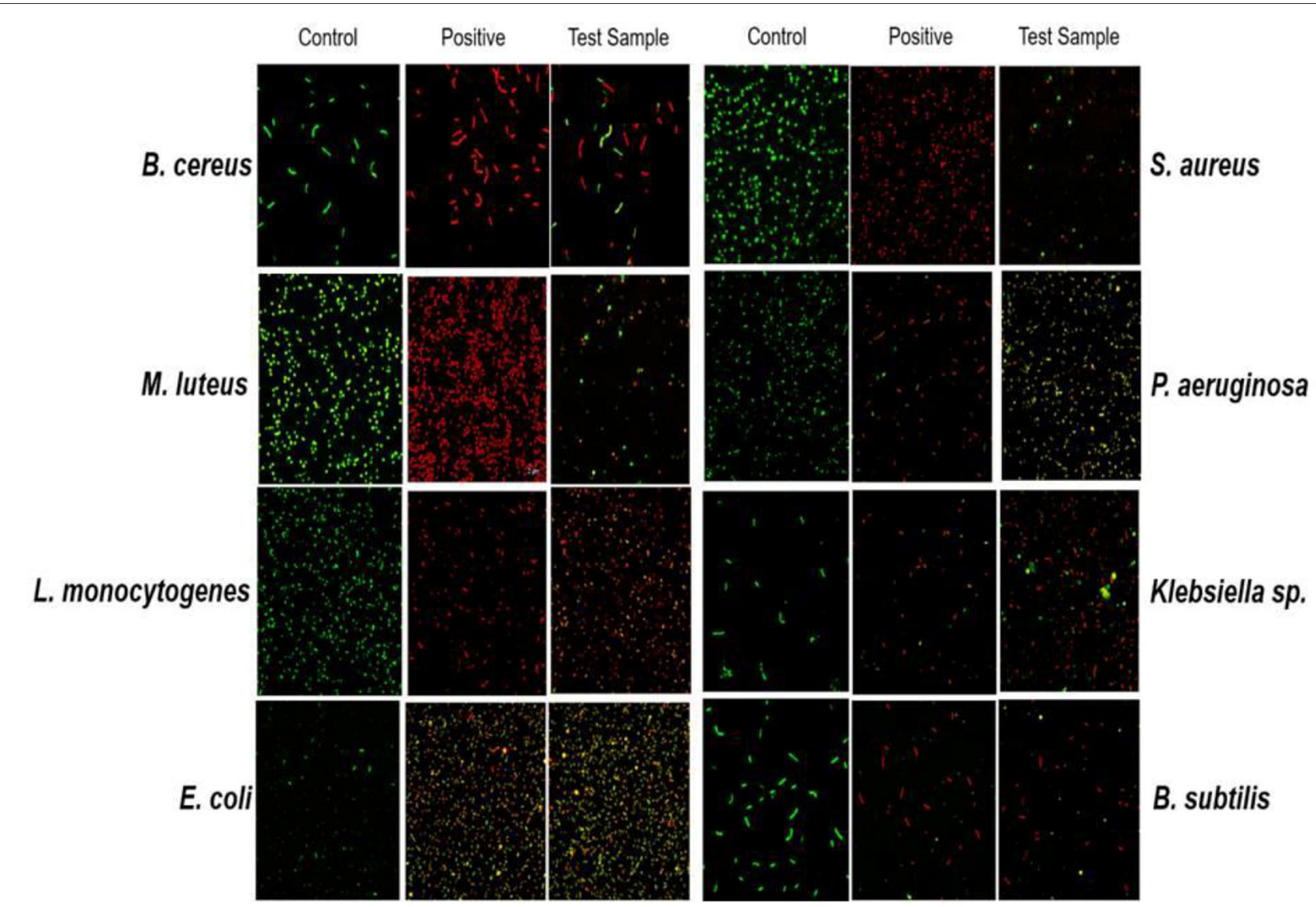

FIGURE 2 | Loss of membrane integrity of food-borne pathogens treated with Exiguobacterium sp GM010 pigment (test sample) were analyzed with CLSM using SYTO9/PI staining and compared with tetracycline (positive) and untreated cell (control). All the pictures were taken at 60X.

absorption band at $1,666 \mathrm{~cm}^{-1}$ that was indicative for stretching frequencies of an $\mathrm{C}=\mathrm{O}$ group. The band at about $1,437 \mathrm{~cm}^{-1}$ was indicative for asymmetric vibrations of the carboxylic group. Peaks at $1,000-1,200 \mathrm{~cm}^{-1}$ correlated to C-O-C linkages of sugar components remaining in the extract.

\section{Toxicity Effect}

Toxicity of Exiguobacterium sp GM010 pigment was analyzed by estimating the mortality rate of $A$. franciscana, a relatively rapid way to detect toxic compounds (Meyer et al., 1982). The mortality rates at $100 \mu \mathrm{g} \mathrm{ml}^{-1}$ of pigment were not significantly different at $12 \mathrm{~h}$ intervals of time. However, at 1,000 $\mu \mathrm{g} \mathrm{ml}^{-1}$ the Exiguobacterium sp GM010 has shown $38.33 \pm$ $1.44 \%$ mortality at $36 \mathrm{~h}$ of treatment (Figure 5). The mortality rate (\%) was compared with the Clarkson's toxicity assessment (Clarkson et al., 2004) and it was confirmed the non-toxic effect of Exiguobacterium sp GM010 pigment.

\section{DISCUSSION}

Marine bacteria Streptomyces, Pseudomonas, Pseudoalteromonas, Bacillus, Vibrio, and Cytophaga isolated marine environment have shown various biological activities (Azamjon et al., 2011).
The majority of marine microorganisms are not easily culturable in the laboratory (Valliappan et al., 2014), due to dynamics of nutrient conditions. To isolate maximum number of marine bacteria, five different culture media were used for isolation of bacteria showing broad spectrum antibacterial activity. Further the $\mathrm{NaCl}$ concentration of the isolation media was increased to ensure the isolated bacteria were truly associated with marine niche.

Generally the Gram-positive bacteria are more sensitive to antibiotics compared to Gram-negative bacteria (Nikaido, 1996) and using more Gram positive indicator bacteria may lead to false positive results of more antibiotic-producing bacteria. Hence, the isolated marine bacteria were screened equally against both Gram positive and Gram negative food-borne pathogens (Table 1), to isolate potential marine bacterium (Figure 1D). Among the marine bacteria screened, a bacterium inhibited both Gram positive and Gram negative food-borne pathogens was identified based on morphological, biochemical, and molecular analysis (Figure 1). These results revealed, the isolated bacterium is belongs to the genus Exiguobacterium. Even though there are reports on Exiguobacterium species showing the algicidal ( $\mathrm{Li}$ et al., 2016), antifungal (Selvakumar et al., 2009) and antibacterial (Shanthakumar et al., 2015) effect, there are no report on the 


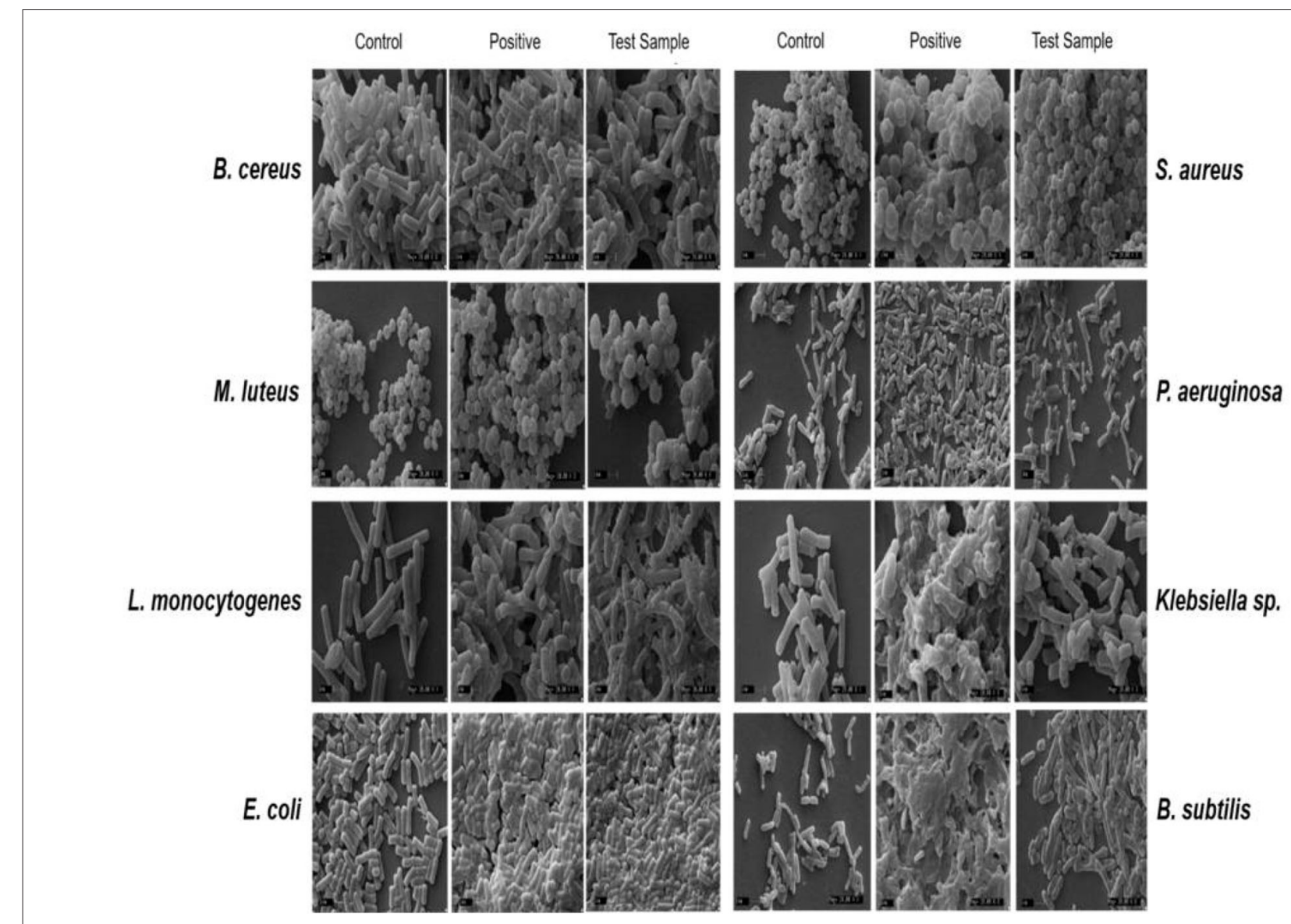

FIGURE 3 | Lysis of food-borne pathogens cells treated with pigment of Exiguobacterium sp GM010 (test sample) and tetracycline (positive) and untreated (control) were observed under SEM. Scale bar- $1 \mu \mathrm{m}$.

antibacterial action of Exiguobacterium sp GM010 pigment and the mechanism of antibacterial action.

The Exiguobacterium sp GM010 pigment has shown antibacterial action against both Gram positive and negative food-borne pathogens. The cellular and membrane integrity is considered important to distinguish between viable and dead bacterial cells for physiological activities (Stiefel et al., 2015). Viable cells have intact membranes and cannot be penetrated by some staining compounds, whereas dead cells are considered to have disrupted or damaged membranes (Stiefel et al., 2015). The CLSM studies suggested that pigment of Exiguobacterium sp GM010 damaged the cell membrane (Figure 2) of food-borne pathogens. The SEM image analysis of the food-borne pathogens treated with pigment have shown shrunken shape compared to the untreated. This is due to the cell membrane damage caused the release of cytoplasmic content and lysis of cell as observed in the figure 3.

Several studies have reported that, functional group of the bioactive compounds can damage the membrane integrity of food-borne pathogens. The hydroxyl group present in the substances of Vibrio sp (Horta et al., 2014) and Pseudoalteromonas phenolica (Isnansetyo and Kamei, 2003) exhibited antibacterial action against B. subtilis and $S$. aureus.
The characteristic functional groups of the algicidal substance produced by the Exiguobacterium sp. h10 mainly included carbonyl, amino, and hydroxyl groups (Li et al., 2016). Similarly 3,6,18-trione, 9,10-dihydro-12-hydroxyl-2methyl-5-(phenyl methyl) (5-alpha, 10-alpha)-dihydroergotamine and dipropyl-Spropyl ester molecules exhibit antibacterial action against clinical pathogens (Shanthakumar et al., 2015). The hydroxyl group of compounds and the presence of a system of delocalized electrons are important for the antimicrobial activity (Ultee et al., 2002). The hydroxyl groups destabilizes the cytoplasmic membrane and acts as a proton exchanger, thereby reducing the $\mathrm{pH}$ gradient across the cytoplasmic membrane. The resulting collapse of the proton motive force and depletion of the ATP pool (Ultee et al., 2002) eventually lead to cell death. This was evidenced by the FTIR spectrum, showing characteristic functional groups that mainly included hydroxyl, carbonyl, and carboxylic groups in Exiguobacterium sp GM010 pigment (Figure 4). These functional group cause a system of delocalized electrons leading to destabilization of membrane and decrease in the membrane potential that resulted in bactericidal action of Exiguobacterium sp GM010 pigment.

Toxicity of GM010 was evaluated by estimating the mortality rate of $A$. franciscana. This assay has been considered as efficient 


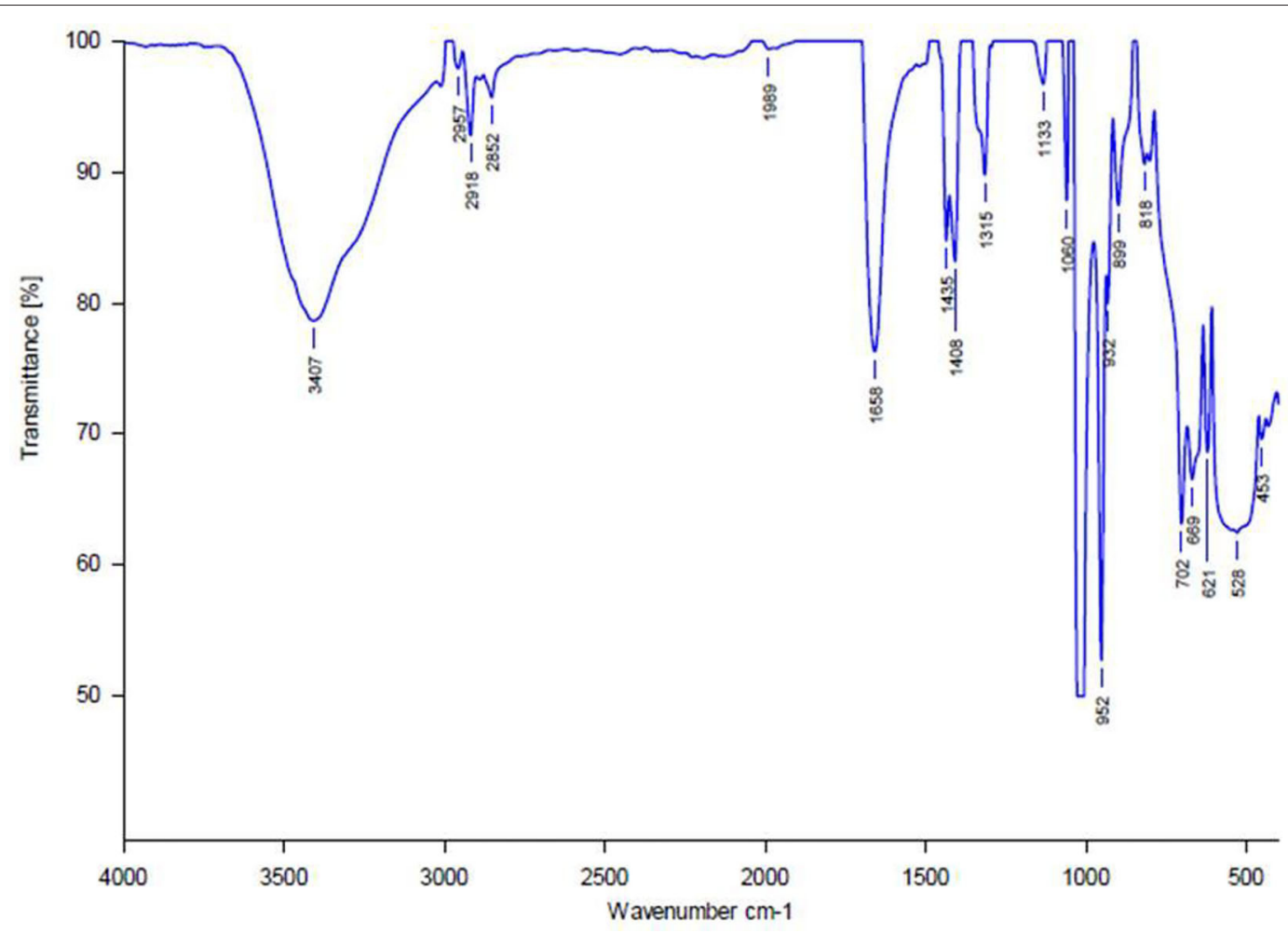

FIGURE 4 | Fourier transform infrared spectrum of Exiguobacterium sp GM010 pigment in the range $400-4,000 \mathrm{~cm}^{-1}$.

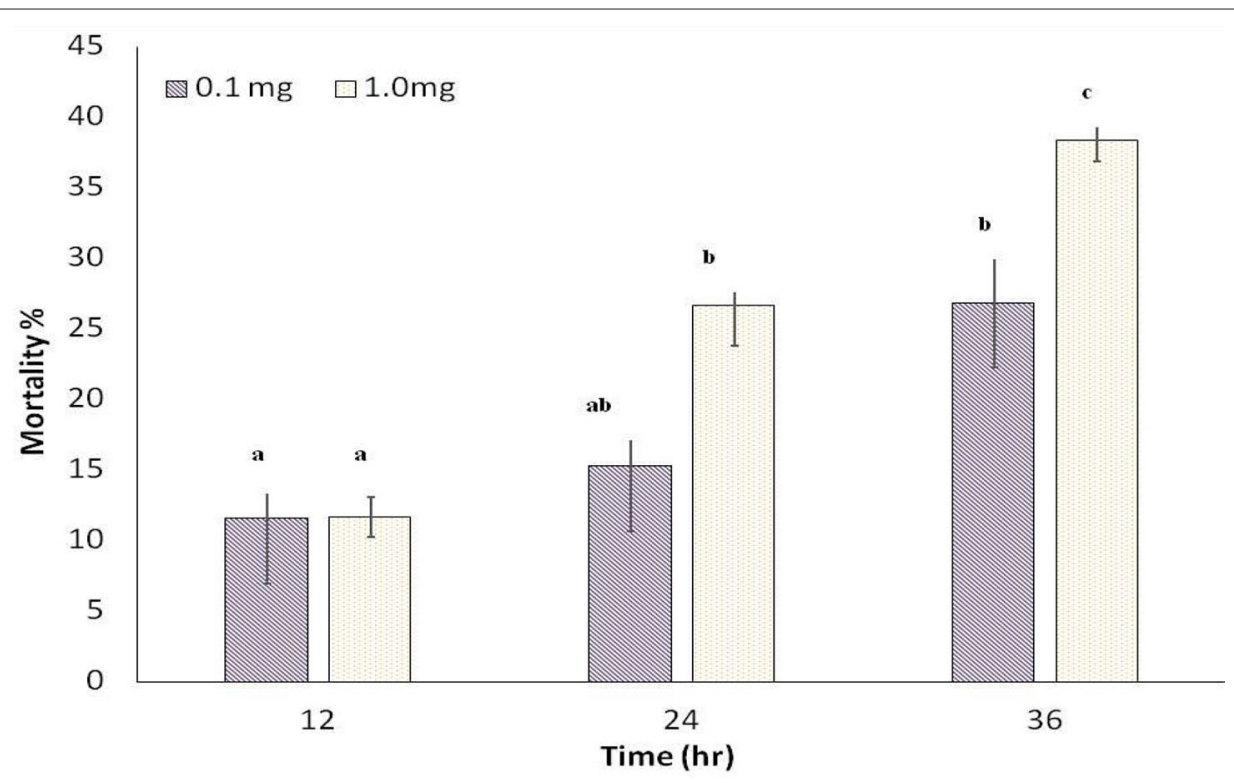

FIGURE 5 | Mortality responses of $A$. franciscana nauplii exposed to 100 and 1,000 $\mu \mathrm{g} \mathrm{ml}^{-1}$ Exiguobacterium sp GM010 pigment. Data represent mean value of three replicate experiments of each concentration. Bars with different letters $(\mathrm{a}, \mathrm{b}, \mathrm{c})$ are significantly different $(P<0.05)$.

inexpensive and a relatively rapid way to detect toxic compounds tool for toxicity assay and requiring only less quantity of sample $(<20 \mathrm{mg})$ (Meyer et al., 1982). At 1,000 $\mathrm{gg} \mathrm{ml}^{-1}$ the GM010 has shown $38.33 \pm 1.44 \%$ mortality at $36 \mathrm{~h}$ of treatment (Figure 5).
Accordingly, extracts with $\mathrm{LC}_{50}$ above $1,000 \mu \mathrm{g} \mathrm{ml}^{-1}$ are nontoxic, $\mathrm{LC}_{50}$ of $500-1,000 \mu \mathrm{g} \mathrm{ml}^{-1}$ are low toxic, extracts with $\mathrm{LC}_{50}$ of $100-500 \mu \mathrm{g} \mathrm{ml}^{-1}$ are medium toxic, while extracts with $\mathrm{LC}_{50}$ of $0-100 \mu \mathrm{g} \mathrm{ml}^{-1}$ are highly toxic (Clarkson et al., 2004). 
The pigment of Exiguobacterium sp GM010 was considered as non-toxic, since the $50 \%$ mortality of $A$. franciscana napuli was not observed at $1,000 \mu \mathrm{g} \mathrm{ml}^{-1}$ concentration.

\section{CONCLUSIONS}

The results of Exiguobacterium sp GM010 pigment showing bactericidal activity against food-borne pathogens and nontoxicity toward $A$. franciscana suggested the application in food preservation and safety efficacy, respectively. Even though the pigment is non-toxic to A. franciscana napuli, additional data on preclinical studies are necessary in order to confirm that pigment is free of cytotoxic effects at different doses of treatment.

\section{DATA AVAILABILITY STATEMENT}

The datasets presented in this study can be found in online repositories. The names of the repository/repositories and accession number(s) can be found in the article/Supplementary Material.

\section{AUTHOR CONTRIBUTIONS}

MD conceptualized, designed the experiment, and reviewed the paper. K-PM executed the experiments, data analysis, and wrote

\section{REFERENCES}

Al-zoreky, N. S., and Al-Taher, A. Y. (2015). Antibacterial activity of spathe from Phoenix dactylifera L. against some food-borne pathogens. Ind. Crops Prod. 65, 241-246. doi: 10.1016/j.indcrop.2014.12.014

Asensioa, L., Lopez-Llorcaa, L. V., and López-Jiménezb, J. A. (2005). Use of light, scanning electron microscopy and bioassays to evaluate parasitism by entomopathogenic fungi of the red scale insect of palms (Phoenicococcus marlatti Ckll., 1899). Micron 36, 169-175. doi: 10.1016/j.micron.2004.09.004

Azamjon, B. S., Kakushi, H., and Keiichi, E. (2011). Bioactive pigments from marine bacteria: applications and physiological roles. Evid. Based Complement. Alternat. Med. 2011:670349. doi: 10.1155/2011/670349

Babu, S. S., Mohandass, C., Vijayaraj, A. S., and Dhale, M. A. (2015). Detoxification and color removal of Congo Red by a novel Dietzia sp. (DTS26)-a microcosm approach. Ecotoxicol. Environ. Saf. 114, 52-60. doi: 10.1016/j.ecoenv.2015.01.002

Bajpai, V. K., Sharma, A., and Baek, K.-H. (2013). Antibacterial mode of action of Cudrania tricuspidata fruit essential oil, affecting membrane permeability and surface characteristics of food-borne pathogens. Food Control 32, 582-590. doi: 10.1016/j.foodcont.2013.01.032

Bandekar, J. R. (2015). "Bacterial food-borne pathogens in Indian food," in Proceedings of the DAE-BRNS Life Sciences Symposium on Advances in Microbiology of Food, Agriculture, Health and Environment (Mumbai: Bhabha Atomic Research Centre).

Blunt, J. W., Copp, B. R., Keyzers, R. A., Munro, M. H. G., and Prinsep, M. R. (2012). Marine natural products. Nat. Prod. Rep. 29, 144-222. doi: $10.1039 / \mathrm{C} 2 \mathrm{NP} 00090 \mathrm{C}$

Blunt, J. W., Copp, B. R., Keyzers, R. A., Munro, M. H. G., and Prinsep, M. R. (2014). Marine natural products. Nat. Prod. Rep. 31, 160-258. doi: $10.1039 / \mathrm{c} 3 \mathrm{np} 70117 \mathrm{~d}$

Burgess, J. G., Jordan, E. M., Bregu, M., Mearns-Spragg, A., and Boyd, K. G. (1999). Microbial antagonism: a neglected avenue of natural products research. J. Biotechnol. 70, 27-32. doi: 10.1016/S0168-1656(99)00054-1

Chandramohan, D. (1997). Recent advances in marine microbiology: the Indian scenario. J. Mar. Biotechol. 5, 73-81. the paper. SP executed the toxicity assay. All the authors read and approved the final manuscript.

\section{FUNDING}

This work was partially supported by Ministry of Earth Science (MoES), Govt of India, New Delhi through financial grantsDrugs From Sea (No. MoES/09-DS/08/2013 PC-IV). K-PM (No. 5/3/14/ITR-F/2018-ITR) and SP (No. 45/36/2013-PHA/BMS) acknowledge Indian Council of Medical Research, New Delhi for providing Research Fellowship.

\section{ACKNOWLEDGMENTS}

We thank Director, CSIR-CFTRI, Mysore, India for encouragement and providing the facility. Few food-borne pathogens were kindly donated by Dr. Prakash Halami, Chief Scientist, CSIR-CFTRI, Mysore.

\section{SUPPLEMENTARY MATERIAL}

The Supplementary Material for this article can be found online at: https://www.frontiersin.org/articles/10.3389/fsufs. 2020.00142/full\#supplementary-material

Clarkson, C., Maharaj, V. J., Crouch, N. R., Grace, O. M., Pillay, P., Matsabisa, M. G., et al. (2004). In vitro antiplasmodial activity of medicinal plants native to or naturalized in South Africa. J. Ethnopharmacol. 92, 177-191. doi: 10.1016/j.jep.2004.02.011

Demain, A. L., and Sanchez, S. (2009). Microbial drug discovery 80 years of progress. J. Antibiot. 62, 5-16. doi: 10.1038/ja.2008.16

Dhale, M. A., Divakar, S., Umesh-Kumar, S., and Vijayalakshmi, G. (2007). Characterization of dehydromonacolin-MV2 from Monascus purpureus mutant. J. Appl. Microbiol. 103, 2168-2173. doi: $10.1111 /$ j.1365-2672.2007.03457.x

Fukuda, K. (2015). Food safety in a globalized world. Bull. World Health Organ. 93:212. doi: 10.2471/BLT.15.154831

Horta, A., Pinteus, S., Alves, C., Fino, N., Silva, J., Fernandez, S., et al. (2014). Antioxidant and antimicrobial potential of the Bifurcaria bifurcata epiphytic bacteria. Mar. Drugs 12, 1676-1689. doi: 10.3390/md12031676

Isnansetyo, A., and Kamei, Y. (2003). Pseudoalteromonas phenolica sp. nov., a novel marine bacterium that produces phenolic anti-methicillin-resistant Staphylococcus aureus substances. Int. J. Syst. Evol. Microbiol. 53, 583-588. doi: 10.1099/ijs.0.02431-0

Kim, S.-J., Cho, A. R., and Han, J. (2013). Antioxidant and antimicrobial activities of leafy green vegetable extracts and their applications to meat product preservation. Food Control 29, 112-120. doi: 10.1016/j.foodcont.2012.05.060

Lane, D. J. (1991). 16S/23S rRNA sequencing. Chichester: John Wiley and Sot6ns.

Li, Y., Liu, L., Xu, Y., Li, P., Zhang, K., Jiang, X., et al. (2016). Stress of algicidal substances from a bacterium Exiguobacterium sp. h10 on Microcystis aeruginosa. Lett. Appl. Microbiol. 64, 57-65. doi: 10.1111/lam.12678

Marmur, J. (1961). A procedure for the isolation of deoxyribonuclic acid from the micro-organisms. J. Mol. Biol. 3, 208-218. doi: 10.1016/S0022-2836(61)80047-8

Meyer, B. N., Ferrigni, N. R., Putnam, J. E., Jacobsen, L. B., Nichols, D. J., and McLaughlin, J. L. (1982). Brine shrimp: a convenient general bioassay for active plant constituents. Planta Med. 45, 31-34. doi: 10.1055/s-2007-971236

Newman, D. J., and Cragg, G. M. (2007). Natural products as sources of new drugs over the last 25 years. J. Nat. Prod. 70, 461-477. doi: 10.1021/np068054v

Nikaido, H. (1996). Multidrug efflux pumps of gram-negative bacteria. J. Bacteriol. 178, 5853-5859. doi: 10.1128/JB.178.20.5853-5859.1996 
Nithyanand, P., Manju, S., and Pandian, S. K. (2011). Phylogenetic characterization of culturable actinomycetes associated with the mucus of the coral Acropora digitifera from Gulf of Mannar. FEMS Microbiol. Lett. 314, 112-118. doi: 10.1111/j.1574-6968.2010.02149.x

Pandit, S. G., Makela, K.-P. R., Puttananjaiah, M.-K. H., and Dhale, M. A. (2019). Cicer arietinum (Bengal gram) husk as alternative for Talaromyces purpureogenus CFRM02 pigment production: bioactivities and identification. LWT Food Sci. Technol. 116:108499. doi: 10.1016/j.lwt.2019.108499

Pandit, S. G., Harohally, N. V., Puttananjaiah, M.-K. H., and Dhale, M. A. (2018). Functional attributes of a new molecule-2-hydroxymethyl-benzoic acid $2^{\prime}$ hydroxy-tetradecyl ester isolated from Talaromyces purpureogenus CFRM02. Food Chem. 255, 89-96. doi: 10.1016/j.foodchem.2018.02.034

Selvakumar, G., Joshi, P., Nazim, S., Mishra, P. K., Kundu, S., and Gupta, H. S. (2009). Exiguobacterium acetylicum strain 1P (MTCC 8707) a novel bacterial antagonist from the North Western Indian Himalayas. World J. Microbiol. Biotechnol. 25, 131-137. doi: 10.1007/s11274-008-9874-4

Shanthakumar, S. P., Duraisamy, P., Vishwanath, G., Selvanesan, B. C., Ramaraj, V., and Vasantharaj, B. D. (2015). Broad spectrum antimicrobial compounds from the bacterium Exiguobacterium mexicanum MSSRFS9. Microbiol. Res. 178, 59-65. doi: 10.1016/j.micres.2015. 06.007

Shnit-Orland, M., and Kushmaro, A. (2009). Coral mucus-associated bacteria: a possible first line of defense. FEMS Microbiol. Ecol. 67, 371-380. doi: 10.1111/j.1574-6941.2008.00644.x

Stiefel, P., Schmidt-Emrich, S., Maniura-Weber, K., and Ren, Q. (2015). Critical aspects of using bacterial cell viability assays with the fluorophores SYTO9 and propidium iodide. BMC Microbiol. 15, 36-45. doi: 10.1186/s12866-0150376-x
Strawn, L. K., Fortes, E. D., Bihn, E. A., Nightingale, K. K., Gröhn, Y. T., Worobo, R. W., et al. (2013). Landscape and meteorological factors affecting prevalence of three food-borne pathogens in fruit and vegetable farms. Appl. Environ. Microbiol. 79, 588-600. doi: 10.1128/AEM.02491-12

Ultee, A., Bennik, M. H. J., and Moezelaar, R. (2002). The phenolic hydroxyl group of carvacrol is essential for action against the foodborne pathogen Bacillus cereus. Appl. Environ. Microbiol. 68, 1561-1568. doi: 10.1128/AEM.68.4.1561-1568.2002

Valliappan, K., Sun, W., and Li, Z. (2014). Marine actinobacteria associated with marine organisms and their potentials in producing pharmaceutical natural products. Appl. Microbiol. Biotechnol. 98, 7365-7377. doi: 10.1007/s00253-014-5954-6

Wiese,. J., and Imhoff, J. F. (2019). Marine bacteria and fungi as promising source for new antibiotics. Drug Dev. Res. 80, 24-29. doi: 10.1002/ddr.21482

World Health Organization (2020). Food Safety. Available online at: https://www. who.int/news-room/fact-sheets/detail/food-safety

Conflict of Interest: The authors declare that the research was conducted in the absence of any commercial or financial relationships that could be construed as a potential conflict of interest.

Copyright (c) 2020 Mekala, Pandit and Dhale. This is an open-access article distributed under the terms of the Creative Commons Attribution License (CC BY). The use, distribution or reproduction in other forums is permitted, provided the original author(s) and the copyright owner(s) are credited and that the original publication in this journal is cited, in accordance with accepted academic practice. No use, distribution or reproduction is permitted which does not comply with these terms. 